\title{
INNOVATION OF EDUCATION AND EDUCATIONAL INNOVATIONS IN CONDITIONS OF MODERN HIGHER EDUCATION INSTITUTION
}

\author{
HALYNA MYKHAILYSHYN, OKSANA KONDUR, LESIA SERMAN
}

\begin{abstract}
The article describes the different approaches to the interpretation of educational innovations and innovations in education. The modern labor market requires graduates ability to operate such technologies and knowledge that meet the needs of the information society, prepare young people for new roles in this society.

It is necessary to distinguish between the concepts "educational innovations" and "innovations in education". Innovation in education is a broader concept than educational innovation. They include educational, scientific and technological, infrastructural, economic, social, legal, administrative and other innovations. Educational innovations are understood as a procedure or method of educational activity that differs significantly from established practice and is used to increase the level of efficiency in a competitive environment. Educational innovations include pedagogical innovation, scientific and methodological innovation, educational and technological innovation. It is substantiated that the education market is one of the most important elements of the national innovation system. Higher education institutions that have chosen an innovationbased development, become competitive leaders on the education market. The formation of new forms of education and the use of perfect controlling mechanisms at each educational institution will give the opportunity to create single educational space, which is able to meet the needs of society in quality education with specific opportunities of customers in the educational market. The main components of the innovation development of higher education institutions are determined.
\end{abstract}

Keywords: innovations, education, higher education institutions, innovation development, education market.

\section{INTRODUCTION}

In all spheres of human life and society general civilizational trends of development, typical for the XXI century, strengthen themselves increasingly. First of all, this is a trend of convergence of nations, people, states through the creation of common economic, information space, and considering the demands of the globalized world, European educational space. The second trend is a shift of humanity from industrial to scientific and informative technology and the formation of a knowledge society, that advances education and research (areas that ensure the development of human and society) as major priority [7, p. 22], that particularly updates the problems of innovation in education area. 
Limits of growth of modern civilization are determined by education, its quality and accessibility. In conditions of growing dynamics of social and economic transformation practice requires the working out of the new forms for educational and social adaptation, optimization of the interests of the state and the individuality in the society of knowledge that appears daily. Global processes became the subject of studying various, especially social sciences. After all, globalization transforms the relations within a society and among countries, causing the formation of a single market space.

The global economic crisis in a globalized society and social and economic relations led to a reorientation of main values and search of the model for economic development by the countries of the European Union that would ensure national competitiveness and direct the national economy of each country to long-term growth. It has become a model of innovation. The European choice of Ukraine has also caused the necessity for the formation and implementation of this model, which should ensure high and stable economic growth, solve social and environmental problems, provide competitiveness of the national economy, increase export potential of the country, to ensure her economic safety and a leading place in the European Union.

The desire to look in the future, predicts and influences it, is imminent to human nature. The real mechanism to influence our future is a distinct sphere of human culture, education. Exceptionally it is able not only to see, but also to define the future in all fields of society - from the competitive economy to a basic and applied science nowadays.

The leading principle of the state policy in the sphere of higher education in Ukraine is the principle of state support for educational, scientific, technological and innovation activities of higher education institutions (HEIs) [13]. Innovative processes in the system of education provide variation and personality oriented trend of the educational process, so that the knowledge, skills and abilities of students are transformed into a means of developing their cognitive and personal qualities, competence to ensure their ability to be the subject of innovative professional activities.

The purpose of the study is to analyze different approaches to the interpretation of educational innovations and innovations in education, and argumentation of actuality of innovation development in higher education institution.

\section{RESUlTS AND DisCUSSION}

The development of informative and innovative technologies advanced science and education as a priority and necessary precondition for the evolution of post-industrial society, in which the system of educational services must transmit competence and everyday knowledge to future professionals. According to Ukrainian scientists V. Heits, V. Semynozhenko, B. Kvasniyk source of growth in economy knowledge is both specialized (scientific) and everyday knowledge, resulting in common with natural resources, capital and work the processes of accumulation and use of knowledge become a dominant factor, that cause the growing competitiveness of the economy [3, p.31]. Knowledge is transforming into essentially incomplete technologies of forming the future actually closing on itself both an economic and social system of post-industrial society.

Education and science are deeply integrated into the economy, social life, and their level significantly affects the quality of life and the possibility of constant development both a separate country in particular and the international community in general. Therefore, science and skilled staff are recognized in Europe to be the decisive factor in achieving the goals of internationalization of the educational process: to make European education more competitive, dynamic, and able to ensure sustainable growth, employment of the population and social cohesion.

The modern labor market requires graduates ability to operate such technologies and knowledge that meet the needs of the information society, prepare young people for new roles in this society.

As V. Andrushchenko says "today not only the ability to operate one's own knowledge is important, but also to be prepared to change and adapt to the new needs of the labor market, operate and manage information, act quickly, make decisions, learn lifelong" [1, p. 8]. Market conditions determine the development path of high school; become a catalyst for the transformation of the 
traditional system of education provision. The main task of higher education system is to ensure the continuous training of human resources for profitable use in constantly changeable conditions of formation global market space.

Effectiveness of the education system depends on a number of internal factors; they are resource base, human resources, forms of operation. At that the adequacy of the education system with the requirements of the national economy, the population in general and individuals play an important role. This need not only updates the quantitative growth of the sphere, but also qualitative shift towards innovative component of education. Thus, one could confirm that the education market is one of the most important elements of the national innovation system.

At present, inefficiency, quantitative and qualitative deformation is inherent to higher education in Ukraine that adversely affects the qualification of citizens; reduces the global competitiveness of our country.

Competition as one of the elements of any market environment improves the quality of specialists training, as it forces HEIs to provide qualified professional standards for employees. Market of educational services through competitive mechanisms literally promotes participation in innovation processes. Competition based on innovation, their quality and timeliness are an important characteristic of HEIs survival, serves as a crucial factor of the development and implementation for new scientific products. Higher education institutions that have chosen an innovation-based development, become competitive leaders on the education market. Since only innovative HEIs are able to adapt to change quickly, innovation is becoming a major factor in their competitiveness in the market [5].

Thus, the modern market of educational services in the Ukrainian higher education recently has not turned into a full-fledged economy sector yet, able to produce competitive human capital. However, the formation of new forms of education and the use of perfect controlling mechanisms at each educational institution will give the opportunity to create single educational space, which is able to meet the needs of society in quality education with specific opportunities of customers in the educational market. Today in the domestic science there is no single approach to the grounding necessity of innovative development in the activities of the HEI and the definition of the concept of such development. Some scientists consider innovation in three aspects: as the science and art of innovation management; as an activity; as the subject of management.

V. Pirus considers innovation to be a new idea or invention that arises and has future that promotes progressive and creative development. Innovation is a source, motivation for development and selfdevelopment [8]. The scientist defines innovative development of the HEI, as an objective, purposeful, irreversible process that expands through time, the transition of HEI from one qualitative state to another, accompanied by internal creative changes. L. Chmelevska, S. Kuzmina, O. Muzychenko note that innovation may be examined as a combination of industrial and intellectual resources, which contributes to the creation of new products and services, uses advanced production methods, source materials and technologies [4, p. 103]. In V. Verbytskyi's opinion, management innovation is the modern economic, psychological, diagnostic, information technologies, which allow to create appropriate conditions for the rapid and effective management decision.

The main innovation areas of management activity enlisted by the scientist are: conceptuality in the institution management; purpose-oriented approach to management; psychological support and humanization of management; modeling the management structure, creating high-speed technologies and mechanisms of management activities; mobile structure of horizontal relationships; bringing management functions in accordance with the tasks of the educational institution; reflexivity of the manager's activity; management of education quality and development of new approaches to determine the effectiveness of educational process; computerization, technologizing of management; adaptation of achievement in science of management in social and industrial areas to the management of educational institutions [12]. Components of innovative development of HEI are shown in Fig. 1. 


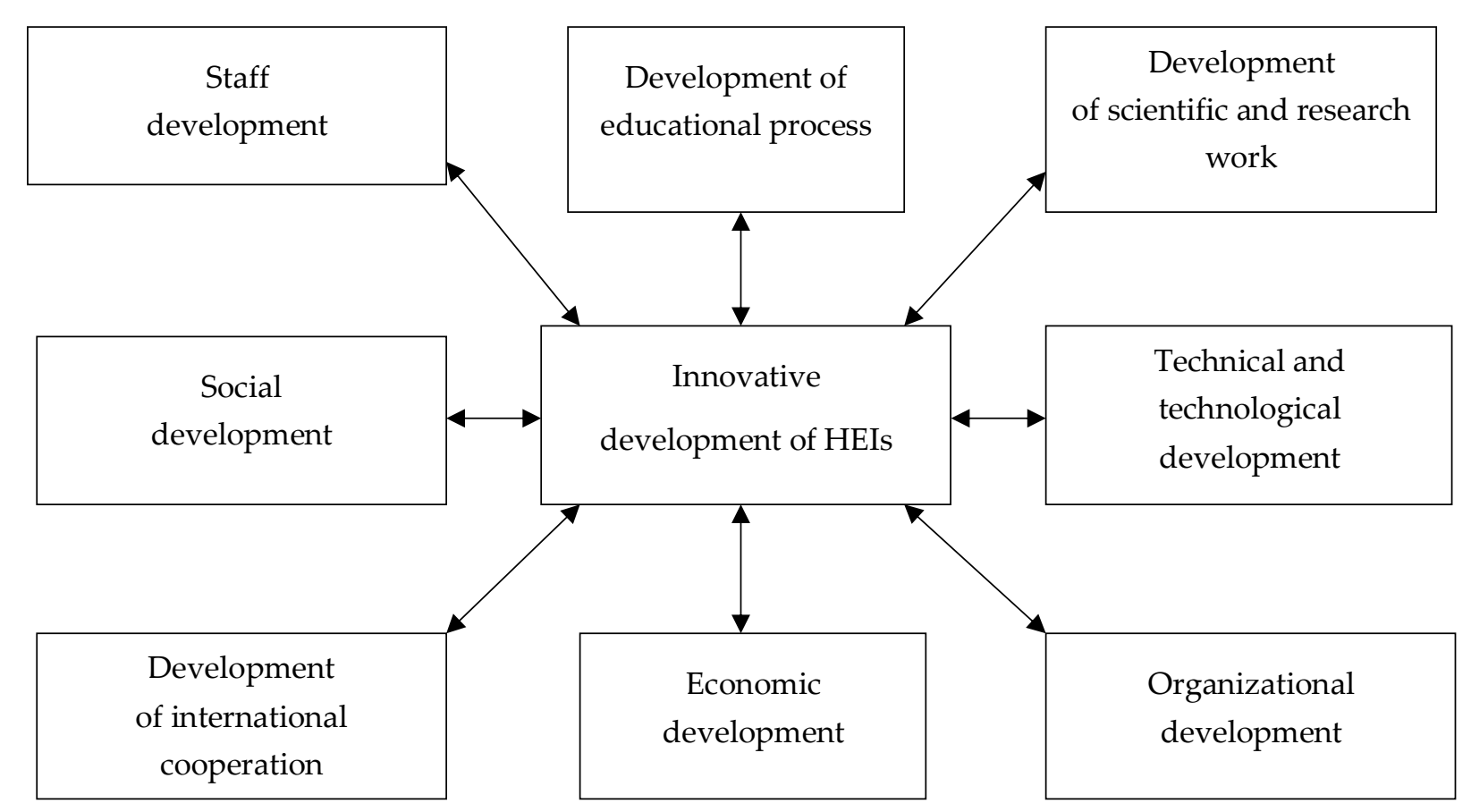

Fig. 1. Components of innovative development of HEI.

In the research of innovative development of HEI V. Safonova's scientific approach should be mentioned. She considers educational activities to be innovational, which is the product of conscious creative work and based on the principle of individualization of initiative in its manifestation [9, p. 233].

Scientists distinguish four main aspects in content-related concept "innovation in education":

1) the process of implementing a new alternative learning strategy to the traditional one, which is creative (productive), not only of reproductive direction;

2) orientation on the realization of person potential in general;

3) mutual action in the process of intuitive creative thinking;

4) promotion of actualization of all forms of intellectual activity under the condition of leading role of productive creative thinking with regard to unproductive, formal and logic [11].

Regarding higher education we should distinguish between the concepts of "educational innovation" and "innovation in education".

Innovation in education is a broader concept than educational innovation. They include educational, scientific and technological, infrastructural, economic, social, legal, administrative and other innovations.

Scientific and technological innovations are the result of research and development in the shape of intellectual property and are transferred for implementation and application in production.

Social innovations include social support for students and university teachers, creating safe conditions for study as well as extracurricular activities of students, formation of socially responsible HEI.

By law, innovations researchers mean the transition to the new organizational and legal form, which is an autonomous educational institution and initiative activities of HEI of working out proposals concerning improvement of education legislation [10, p. 81].

Educational innovations are any purpose-oriented activity, organizational solutions, system, process or method of implementation of educational activities that significantly differ from the established practice and are first used in the institution and are aimed at improving the efficiency of functioning and the development of organization in a competitive environment.

Educational innovations include: 
- pedagogical innovation: the change of style in teaching and the organization of the educational process; introduction of innovative models of education that turn the education character into its essence and instrumentally important characteristics as the purpose-oriented organization; nature of the interaction of the teacher with the students and their position in the learning process; effective organization of educational process, particularly using modern information and communication technologies, etc.;

- scientific and methodological innovation: updating the content of educational programs in accordance with the best domestic and foreign counterparts; introducing of innovative courses; creating of modern content of teaching materials (new textbooks, program, scientific and methodological support);

- education and technological innovation: use of new or improved learning technologies (such as distance education or online learning, Internet technology, project organized technology, etc.); providing students and teachers with access to electronic libraries; creating ACS of educational process and university information system.

The main factors of innovation in internal environment of universities include:

- educational innovations: the content of the curriculum; new teaching technologies; high professionalism of teaching staff; organizational and methodological support of educational process;

- administrative (managerial) innovation: support for innovative university structure; general management system and its properties; management system at the level of structural subdivisions (faculties, departments); system of provision with educational services quality;

- ideological innovation: university participating in the programs, competitions and other events held with the participation of government institution and Ministry of Education of Ukraine;

- availability of state order for specialist training from line ministries; the presence of mechanisms of interaction between universities and the labor market.

Most of the educational innovations are stimulated by consumers of educational services. Some of them belong to the innovation oriented to meet existing needs: to harmonize educational and professional standards, to involve representatives of professional societies to develop educational programs of universities; to develop innovative educational programs by new directions and specialties; practitioners' participation in the educational process and common research [2].

Some innovations are aimed at creating and satisfying of new needs. In the postindustrial society the classic lectures and seminars are replaced by modern project, discussion, search formats with a high degree of independence and activity of students and new cognitive institutions: research networks, virtual laboratories which in a flexible way will organize the resources of various institutions (universities, research institutions, industrial laboratories, etc.) for the implementation of breakthrough projects in science and technology.

Educational innovations are the essence of innovative education. Scientists consider its purpose in creating an optimal and sustainable educational and organizational, scientific and methodological and regulatory and administrative environment that provides support of innovative approaches to the educational process, which are focused on the integration of scientific and educational potential of universities and sectorial science and partnerships with employers.

Such understanding of innovative development enables institutions to implement new approaches to the choice of strategic objectives, based not only on their own interests, but first of all the interests of consumers of innovative education system products: society, state, employees, students and others.

According to philosophers and sociologists' opinion, innovation education is a purposeful process of education and person innovative study; it should facilitate the development of his creative skills, self-learning skills, that is to form his intellectual capital. Characteristic of innovative educational models is shown in Fig. 2. 


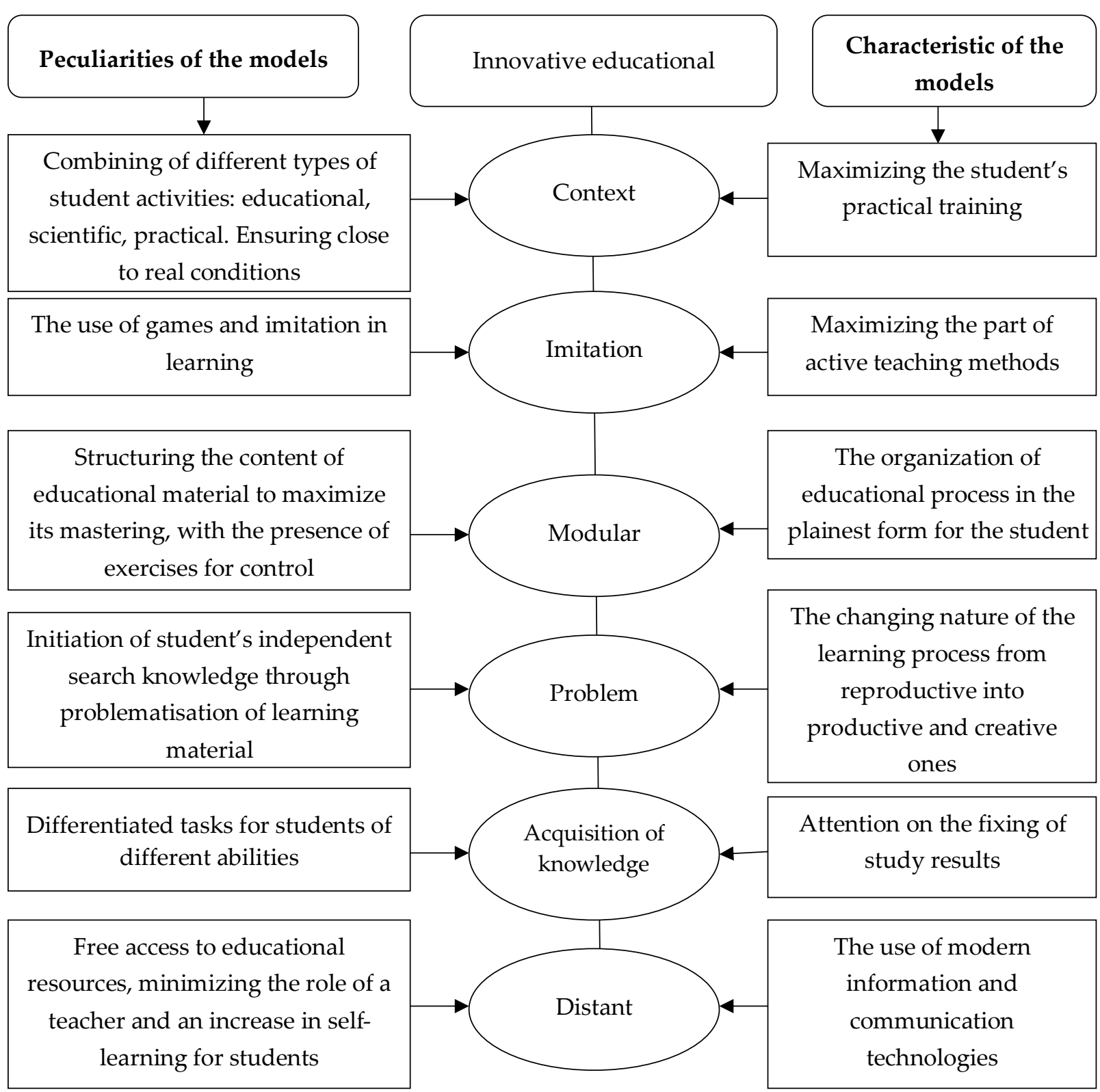

Fig. 2. Characteristic of innovative educational models.

Important tasks that provide innovative direction of HEI are:

- scale computerization and activation of scientific and technological activities of higher education institutions, creating innovative structures in their system; reforming of the education system to meet the requirements of European standards and the preservation of national cultural and intellectual traditions;

- increasing the effectiveness of university sector in research and working out in order to strengthen its role in providing innovative development of the national economy;

- concentration of resources in priority areas of science and technology development and innovation activity; stimulating lifelong learning, education of culture of innovative thinking.

\section{CONCLUSIONS}

So, summing up the reviewed scientific approaches, the main components of an innovative HEI can be outlined. In our view, they are:

- introduction of innovative technologies in educational process [6];

- student-centered educational process; 
- improving the system of organization and management of higher education institution;

- increasing of qualification of stuff potential of higher education;

- development of own research capacity, implementation of scientific research and production of scientific and innovative products;

- formation of the appropriate economic mechanism that will make it possible to obtain additional financial resources and use their savings;

- conducting marketing work to expand the education market and meet the needs of consumers.

Technology transfer, close cooperation with the business sector, implementation of research results into production and the vital activity of society is prerequisite for successful innovational HEI.

\section{REFERENCES}

[1] Andrushchenko V.P. Priorities of the education development of XXI century. Current philosophical and culturological problems of the present, 3-11. Znannya Ukrayiny, Kyiv, 2000. (in Ukrainian)

[2] Babina N.O. Organization of innovative activity of higher educational establishments. Available at: www.stattionline.org.ua. (in Ukrainian)

[3] Heyets V.M., Semynozhenko V.P., Kvasnyuk B.Ye. Strategic challenges of the $21^{\text {st }}$ century for the society and economy of Ukraine. Feniks, Kyiv, 2007. (in Ukrainian)

[4] Khmelevska L.P., Kuzmina S.A., Muzychenko O.A. Creation of the concept of innovational education as the basis for further economic development of the state. Visnyk KNUTD, 4 (66) (2012), 102-107. (in Ukrainian)

[5] Leebron D. A look at the competitiveness of higher education. Available at: http://thehill.com/blogs/ pundits-blog/209980-a-look-at-the-competi-tiveness -of-higher-education.

[6] Lutsan N., Mykhaylyshyn G., Kondur O. Modern educational technologies in Ukrainian high school. Edukacja-Technika-Informatyka: Kwartalnik naukowy, 4 (14) (2015), 74-79.

[7] Natroshvili S.H. Organization of innovative activity of institutions of higher education. Ekonomika $i$ upravlinnya, 1 (2014), 21-25. (in Ukrainian)

[8] Pirus V.O. Formation of innovational development of the educational institution: theoretical aspects. Available at: www.stattionline.org.ua. (in Ukrainian)

[9] Safonova V.Ye. Innovation and innovative capacity of the education system: the economic and theoretical aspect. Universytets'ki naukovi zapysky Khmel'nyts'koho universytetu upravlinnya ta prava, 4 (52) (2014), 230-239. (in Ukrainian)

[10] Shevchenko L.S. Typologization of innovation activity and innovation in the educational sphere. Pravo ta innovatsiyi, 4 (2013), 78-91. (in Ukrainian)

[11] Vashchenko V.P. Innovative education: conditionality and essence. Available at: http://www.riep.ru. (in Russian)

[12] Verbyts'kyy V.V. Innovative technologies in the management of an educational institution. Available at: http://www.stattionline.org.ua. (in Ukrainian)

[13] Law of Ukraine “On Higher Education". Available at: http://zakon3.rada.gov.ua/laws/show/1556-18. (in Ukrainian)

Address: Halyna Mykhailyshyn, Oksana Kondur, Lesia Serman, Vasyl Stefanyk Precarpathian National University, 57, Shevchenko Str., Ivano-Frankivsk, 76018, Ukraine.

E-mail: galmuh60@gmail.com, oxikon13@gmail.com.

Received: 14.11.2017; revised: 12.03.2018. 
Михайлишин Галина, Кондур Оксана, Серман Аеся. Інновації в освіті та освітні інновації в умовах сучасного вищого навчального закладу. Журнал Прикарпатського університету імені Василя Стефаника, 5 (1) (2018), 9-16.

У статті описано різні підходи до трактування освітніх інновацій та інновацій в освіті. Сучасний ринок праці вимагає від випускників закдадів вищої освіти вміння оперувати такими технологіями та знаннями, які задовольняють потреби інформаційного суспільства, готують мододь до нових ролей у ньому.

Акцентовано на необхідності диференціації понять "освітні інновації" та "інновації в освіті". Автори стверджують, що “інновації в освіті" є більш широким поняттям, ніж “освітні інновації”. Вони охоплюють освітні, науково-технологічні, інфраструктурні, економічні, соціальні, юридичні, управлінські та інші інновації. 3'ясовано, що під освітніми інноваціями розуміють процедуру чи метод здійснення освітньої діяльності, які суттєво відрізняються від усталеної практики та спрямовані на підвищення рівня ефективності функціонування в умовах конкуренції. Освітні інновації охопдюють: педагогічні інновації, науково-методичні інновації, освітньо-технологічні інновації. Обгрунтовано, що ринок освітніх послуг є одним 3 найваждивіших елементів національної інноваційної системи. Доведено, що заклади вищої освіти, які обрали інноваційний шлях розвитку, стають простором, який здатен задовольнити потреби суспільства у високоякісній освіті 3 урахуванням конкретних можливостей споживачів на ринку освітніх послуг. Визначено основні скдадові інноваційного розвитку закладів вищої освіти.

Ключові слова: інновації, освіта, заклад вищої освіти, інноваційний розвиток, ринок освітніх послуг. 